Article

\title{
Evaluation of Slope Stability Considering the Preservation of the General Patrimonial Cemetery of Guayaquil, Ecuador
}

\author{
Fernando Morante ${ }^{1,2, *}$, Maribel Aguilar ${ }^{2,3}$, Gonzalo Ramírez ${ }^{2,3}$, Roberto Blanco ${ }^{2,4}$,
} Paúl Carrión ${ }^{2,3, *}$, Josué Briones ${ }^{2}$ and Edgar Berrezueta ${ }^{5}[$

1 Facultad de Ciencias Naturales y Matemáticas (FCNM), Geo-recursos y Aplicaciones GIGA, ESPOL Polytechnic University, Escuela Superior Politécnica del Litoral, ESPOL, Campus Gustavo Galindo Km 30.5 Vía Perimetral, P.O. Box 09-01-5863, Guayaquil, Ecuador

2 Centro de Investigaciones y Proyectos Aplicados a las Ciencias de la Tierra (CIPAT), ESPOL Polytechnic University, Escuela Superior Politécnica del Litoral, ESPOL, Campus Gustavo Galindo Km 30.5 Vía Perimetral, P.O. Box 09-01-5863, Guayaquil, Ecuador; maesagui@espol.edu.ec (M.A.); goanrami@espol.edu.ec (G.R.); rblanco@espol.edu.ec (R.B.); briones@espol.edu.ec. (J.B.)

3 Facultad de Ingeniería Ciencias de la Tierra (FICT), ESPOL Polytechnic University, Escuela Superior Politécnica del Litoral, ESPOL, Campus Gustavo Galindo Km 30.5 Vía Perimetral, P.O. Box 09-01-5863, Guayaquil, Ecuador

4 Facultad de Geología y Minas, Instituto Superior Minero Metalúrgico (ISMM), Avenida Calixto García 15, 83300 Moa, Cuba

5 Instituto Geológico y Minero de España (IGME), C/Matemático Pedrayes 25, 33005 Oviedo, Spain; e.berrezueta@igme.es

* Correspondence: fmorante@espol.edu.ec (F.M.); pcarrion@espol.edu.ec (P.C.); Tel.: +593-98-829-2937 (F.M.); +593-99-826-5290 (P.C.)

Received: 29 December 2018; Accepted: 20 February 2019; Published: 26 February 2019

\begin{abstract}
Inefficient blasting techniques and poor closure management of the old quarry that existed during the 1970s in the area of the actual General Patrimonial Cemetery of Guayaquil resulted in an almost vertical slope of approximately $50 \mathrm{~m}$ in height and an intense induced fracturing that weakened the rock mass. This led to the loss of stability and increased material detachment, which damaged the infrastructure of the graveyard representing a risk to visitors and workers. The aim of this research is to evaluate the slope stability through a geotechnical analysis that allows decision-making to recover and preserve the safety of the area. In this work, we used structural measurements and observations made in the field, as well as a three-dimensional model of the slant generated by photographs taken by a drone. Slope Mass Rating (SMR) and Chinese Slope Mass Rating (CSMR) rankings were used to evaluate stability, susceptibility to rockfall was determined using a theoretical-practical procedure, and the safety factor was calculated using the Morgenstern-Price method. The analysis of the geomechanical classifications yielded a low stability value of the slope, which was in accordance with the high susceptibility to rockfall and with the low safety factor. Based on these results, we recommend the application of systematic bolt and shotcrete for stabilization.
\end{abstract}

Keywords: detachment susceptibility; geomechanical characteristics; CSMR; slope stability; SMR

\section{Introduction.}

A slope is an inclined surface, often present on geological structures of the earth [1]. The slopes can be formed naturally or, as in the studied case, can be the result of anthropic activity [2]. Slopes and mass movements associated with them are considered geological environmental threats [3]. 
The stability of a slope is affected by geological, hydrogeological, and geometric factors; topographic conditions; and the geomechanical behavior of the ground $[4,5]$. The weight of the rocks and the water saturation are two decisive factors in the stability of a rock mass [6]. According to [1], stability is a safety parameter that can be explained as the ability of a land mass to maintain its structure without failing or moving. It can be described by a safety factor [7], which is also a requirement for stabilization intervention recommendations.

The object of the present study is the General Patrimonial Cemetery of Guayaquil. Important people have been buried here, including war heroes, presidents, and artists, who contributed to the development of the country [8]. In 2003, the cemetery was declared Cultural Patrimony of the Nation [9].

The graveyard was expanded and partly built over a scarp left behind by the municipal quarry that operated here during the 1970s.

The basting methods used in the former quarry created an almost vertical slope and induced a series of fractures in the massif that weakened the whole scarp over time, increasing its instability and resulting in the detachment of material. Rockfalls have occurred in the escarpment that have damaged the infrastructure of the Patrimonial Cemetery, such as mausoleums, niches, sculptures, and other buildings, which characterize this heritage of Ecuadorian culture. This also affected the moral and spiritual values of the graveyard.

Considering the unstable conditions of the escarpment located within the cemetery (Gate 1), this study aims at (i) the geomechanical characterization of sedimentary rocks in the studied area (Cemetery of Guayaquil) and (ii) the assessment of the value of data (stability, susceptibility to detachment, and safety factor) obtained from outcrop samples for the estimation of slope stability. Therefore, this paper provides an overview of the process and the results of a characterization methodology that can serve as a basis for more detailed and specific studies of slope stability in similar cases.

\section{Geographical and Geological Environment}

The study area is located in the declivity of the General Patrimonial Cemetery of Guayaquil, which is at the foot of the escarpment of Cerro del Carmen, facing Julián Coronel street, entering through Gate 1 (Figure 1). The cemetery covers an area of approximately 130,000 $\mathrm{m}^{2}$ and the slope where we worked is around $50 \mathrm{~m}$ high.

The geological formations underlying Guayaquil are described below in order of age, from the oldest to the youngest:

The Piñón Formation, which, according to [10], is an Upper-Albian-Aptian formation, consists mainly of aphanitic basalts with a pad structure and siliceous shale intercalations in the vicinity of Guayaquil.

The Calentura Formation, of Cenomanian-Upper-Turonian age, is composed of a sequence of gray limestone and calcareous lapilli tuffs with tuffaceous shales in the upper part [11].

The Cayo Formation, of Turonian-Conician age [12], is made up of a rhythmic stratification of tuff shales, lapilli tuff, volcanoclastic agglomerates, and gaps of a greenish color [13,14]. The upper part is altered by spherical weathering and contains grayish-beige tuffaceous shales, tuff, and silicified siltstone [15].

The Maastrichtian Guayaquil formation crops out in the study area [12]. In the lower part, it presents silicified shales and chert nodules alternating with brown-colored tuffaceous siltstones [16], while the upper part consists of sandstones with calcareous cement and silicified shales. There is an abundance of fossil remains [17]. 

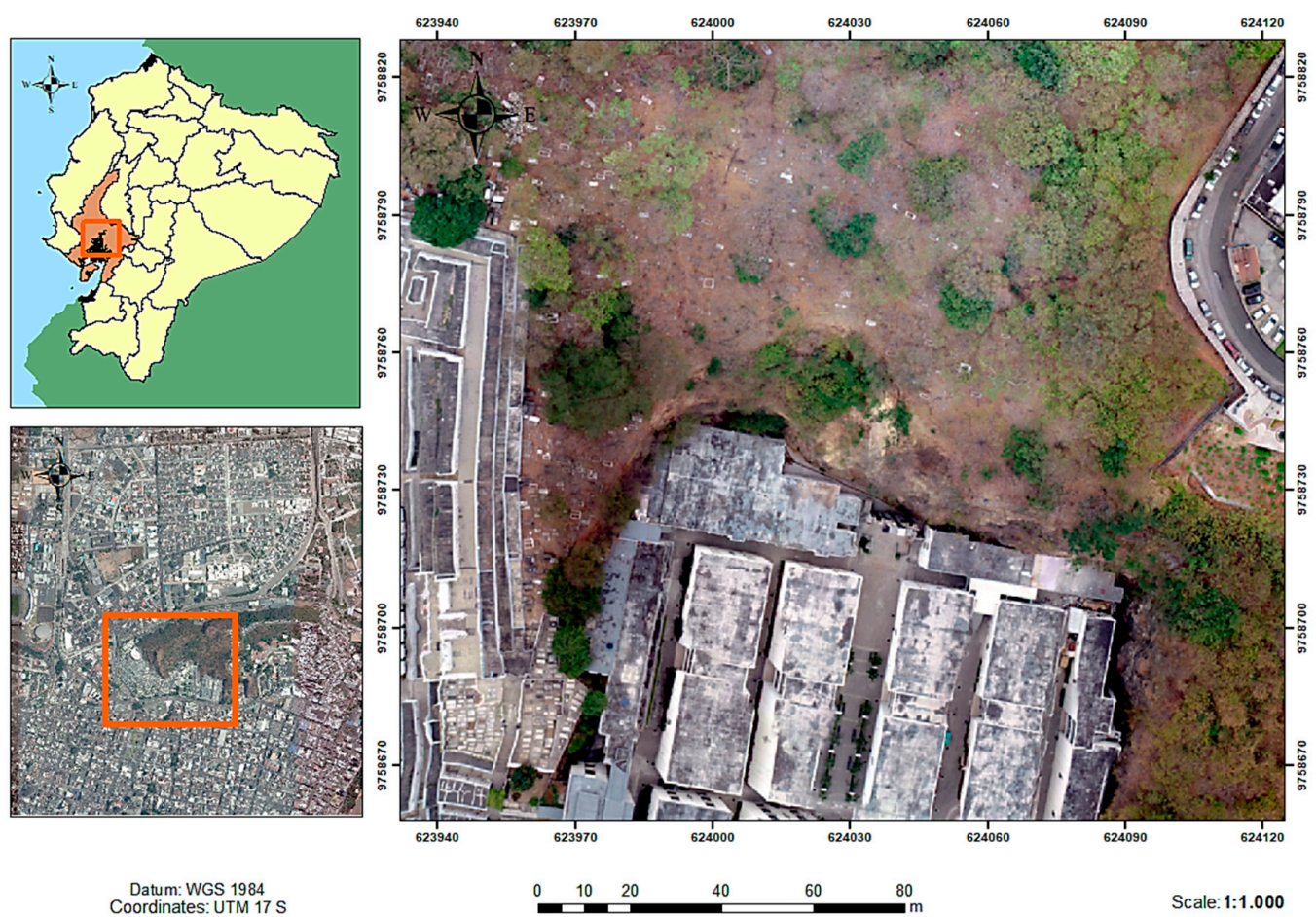

Figure 1. Location map of the study area.

\section{Methodology}

In order to reach our scientific goals, we followed a methodology that combined experimental work (both in situ and in laboratory) with a series of interpretive activities (Figure 2) which was developed in the following three phases:

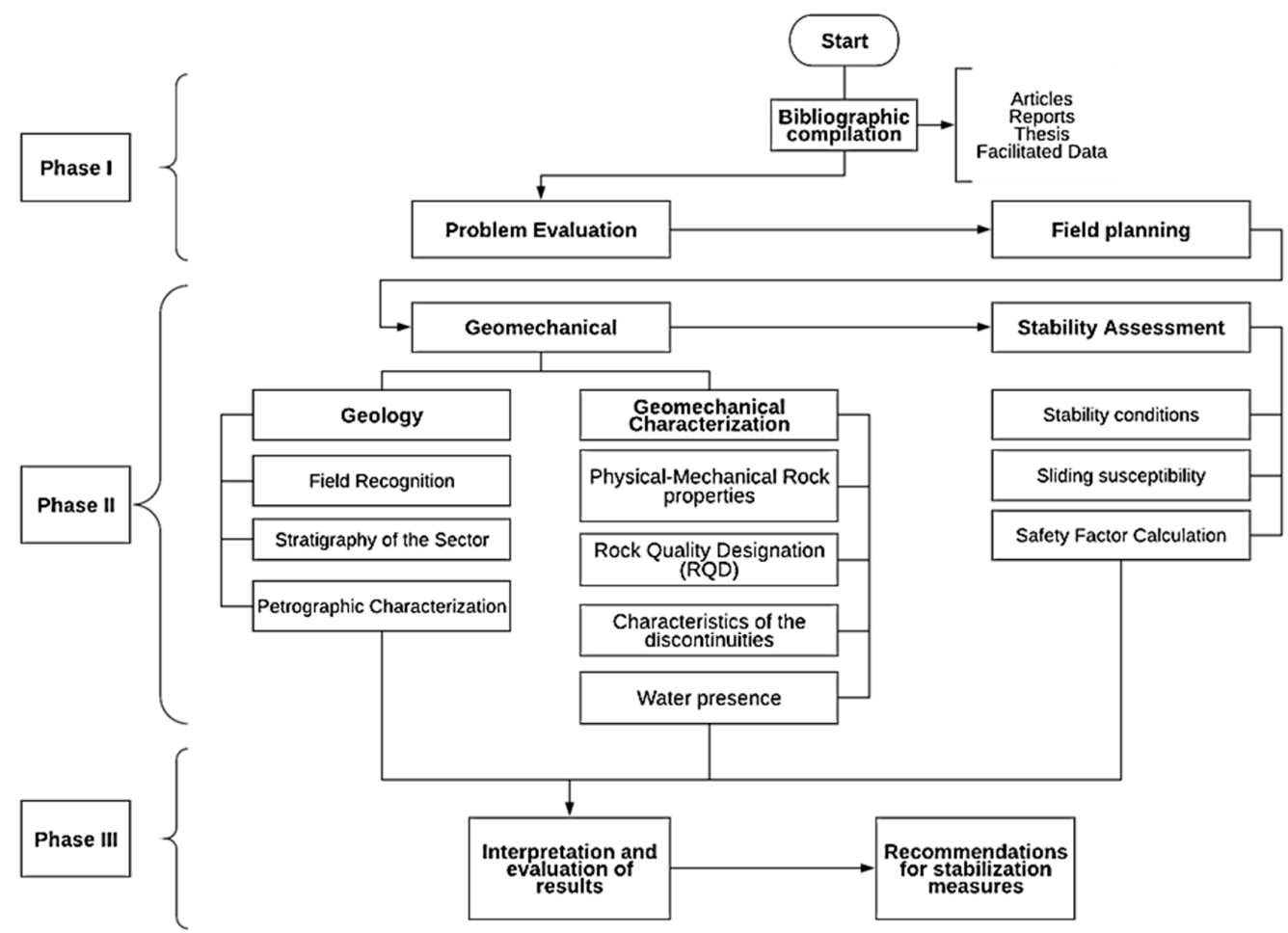

Figure 2. Flowchart of the methodology used in this study. 


\subsection{First Phase}

As a first step, we compiled the relevant bibliography, including articles, reports, and even projects that had been developed in the area, as well as data provided by the "Studies and Proposals for the Stabilization of the Slope in Cerro del Carmen of the General Cemetery (Julián Coronel Street)" project [18]. The literature survey also covered topography, laboratory tests for rocks and soils, and images obtained by a high-resolution drone. In addition, we analyzed the technical and social context considering the causes and the impact of the problem, which helped us assess its importance.

\subsection{Second Phase}

\subsubsection{Geology}

Field work in the General Patrimonial Cemetery of Guayaquil allowed us to study the morphology of the terrain and to obtain strike and dip measurements of the slope, the strata, and the fractures. A representative stratigraphic column was constructed based on the lithological observations, and six samples were taken for their description and laboratory tests to assess physical and mechanical properties.

\subsubsection{Geomechanical Characterization}

\section{Physical-Mechanical Properties}

According to $[19,20]$, rocks, such as shale, mudstone, sandstone, slate, gneiss, schist, coal, and marl, present anisotropic mechanical behavior, and these anisotropic rocks usually play an important role in rock engineering. Therefore, the assessment of mechanical properties (such as compressive, shear, tensile, and fracture behavior) provides crucial information for the study of slope stability.

The physical-mechanical properties are necessary to develop the Slope Mass Rating (SMR) and Chinese Slope Mass Rating (CSMR) methods in order to determine the stability conditions. These properties are also required for the calculation of the safety factor (SF).

Simple linear compression, resistance, density, cohesion, and internal friction angle were measured on the six samples. All tests were performed by a specialized rock mechanics laboratory.

The linear resistance to compression was determined by the "standard" method using cores with a 1.5 height/diameter ratio, while for the tensile strength, the "Brazilian test" method was used. According to [21,22], the Brazilian test is a simple indirect testing method to obtain the tensile strength of brittle material such as concrete, rock, and rocklike materials, in which a thin circular disc is diametrically compressed to failure.

Cohesion and angle of internal friction values were established using circles of Mohr-Coulomb stresses from compressive and tensile strength values, using our own data verified by the results of other works.

\section{Rock Quality Designation (RQD)}

According to $[23,24]$, the RQD is a modified core recovery percentage, in which all pieces of sound core over $100 \mathrm{~mm}$ (4 in.) long are summed and divided by the length of the core run. The RQD index is an index of rock quality "in that problematic rock that is highly weathered, soft, fractures, sheared and jointed is counted against the rock mass" [24].

For field observations, we applied the Priest-Hudson method [25] (Table 1), which takes into account the number of fractures per meter and uses the following formula:

$$
\mathrm{RQD}=100 \times \mathrm{e}(-0.1 \lambda) \times(0.1 \lambda+1)
$$

where $\lambda$ is the average number of discontinuities per meter. 
Table 1. Rock quality designation (RQD) quantitative rating (source: [24]).

\begin{tabular}{cc}
\hline RQD (\%) & Rock Quality \\
\hline 25 & Very Poor \\
$25-50$ & Poor \\
$50-75$ & Fair \\
$75-90$ & Good \\
$90-100$ & Very Good \\
\hline
\end{tabular}

Characteristics of Discontinuities

In soils and rocks, discontinuities act as planes of weakness or as conduits of groundwater flow. These features, according to [26,27], can facilitate movements.

The characteristics of discontinuities were determined by a combination of measurements taken during the field trips and the analysis of high-resolution pictures captured by drone. We assessed:

- the separation between diaclases, which is the average distance between existing fractures in the different sectors of the slope, and

- $\quad$ the state of joints, based on the photographs of the slope acquired with a drone and through in situ observations considering the length of the discontinuity, its opening, roughness, filling, and alteration.

\section{Presence of Water}

According to $[27,28]$ the presence of water generally decreases the shear strength of slope-forming material and thereby increases the probability of slope failure. Since it is difficult to assess subsurface flow of groundwater quantitatively, we used visual estimation of field conditions to award the ratings.

The presence of water in the massif was corroborated during field trips, in which dry and wet sectors and sectors with flowing water were differentiated.

\subsubsection{Geomechanical Characterization}

A three-dimensional model of the slope was generated (Figures 3-5) using photographs taken by a drone. The massif was divided into three zones based on the change in the dip and dip direction, and each zone was divided into sectors (Figures 3 and 6), identifying the main families of discontinuities.

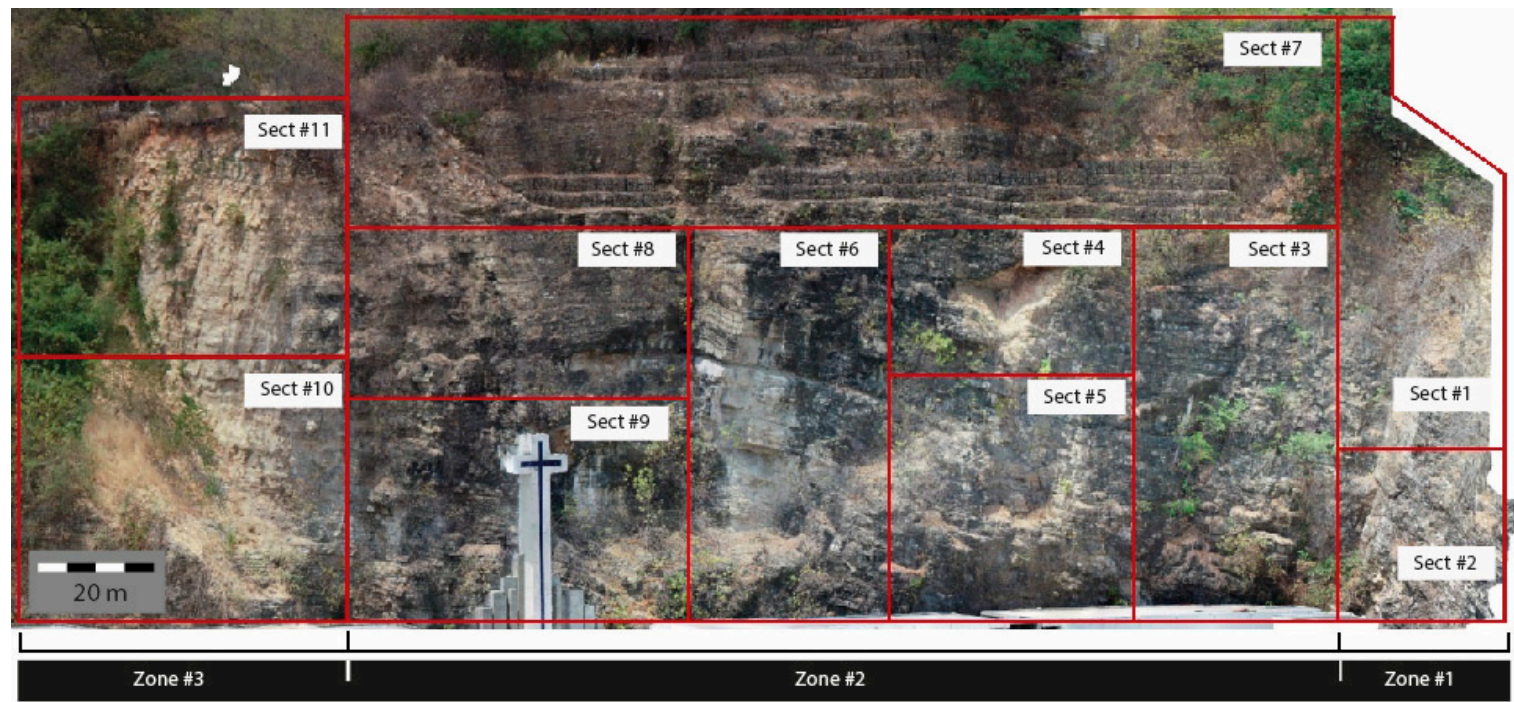

Figure 3. Frontal view of the 3D model of the slope. Division of the slope into zones and sectors. 


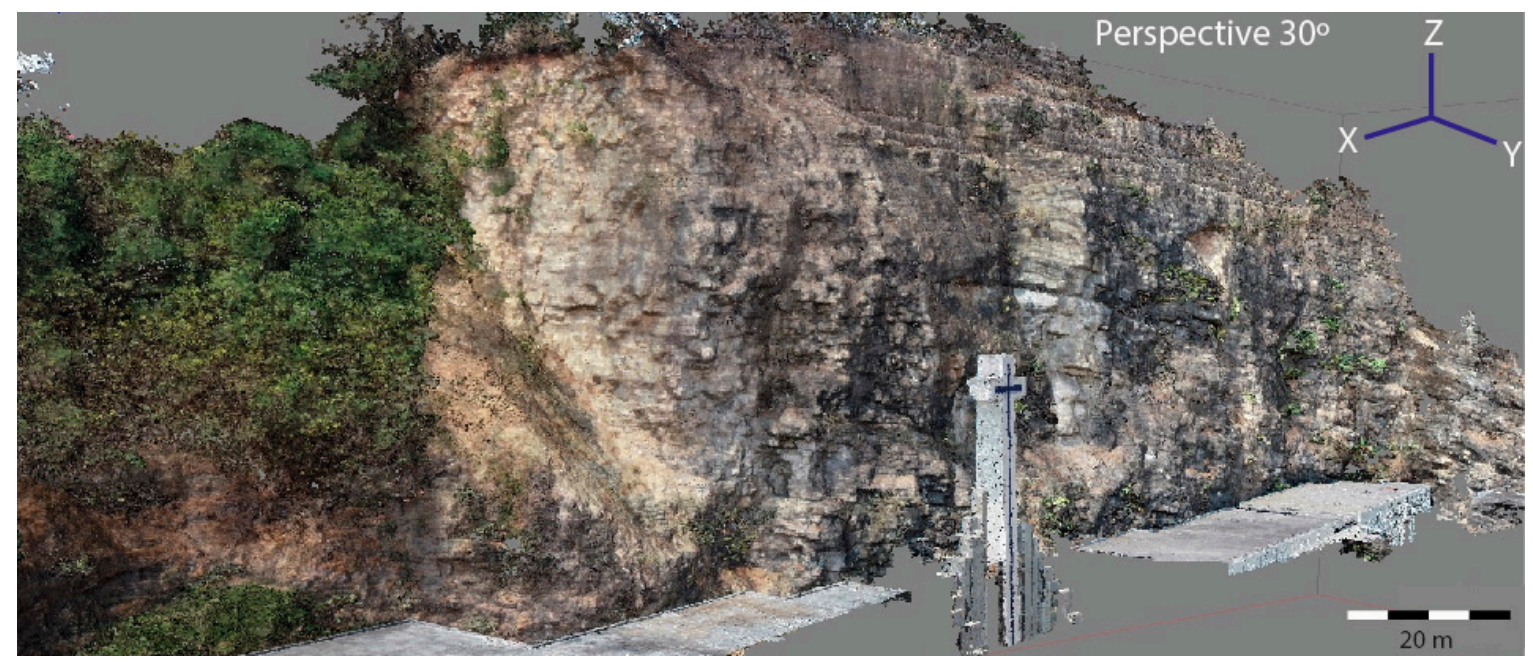

Figure 4. Left view of the 3D model.

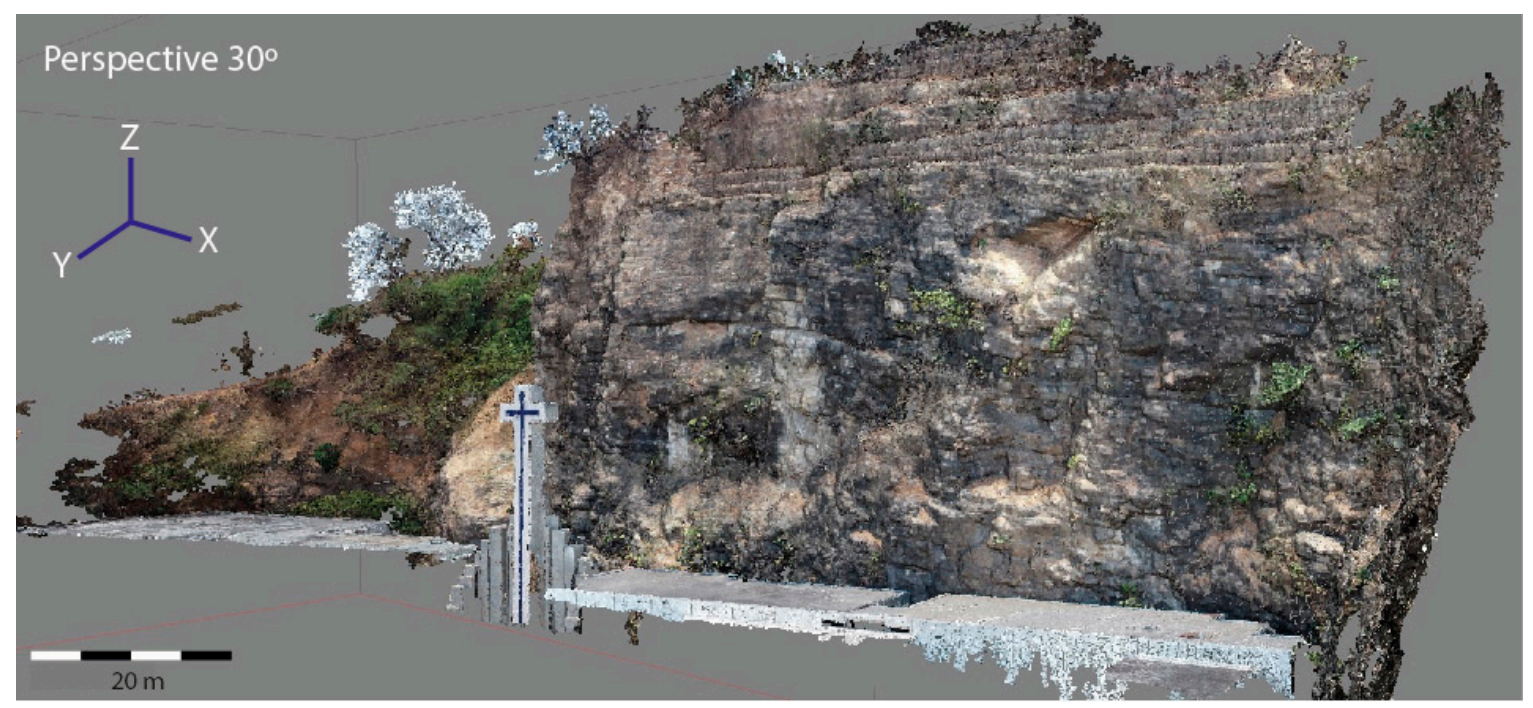

Figure 5. Right view of the 3D model.
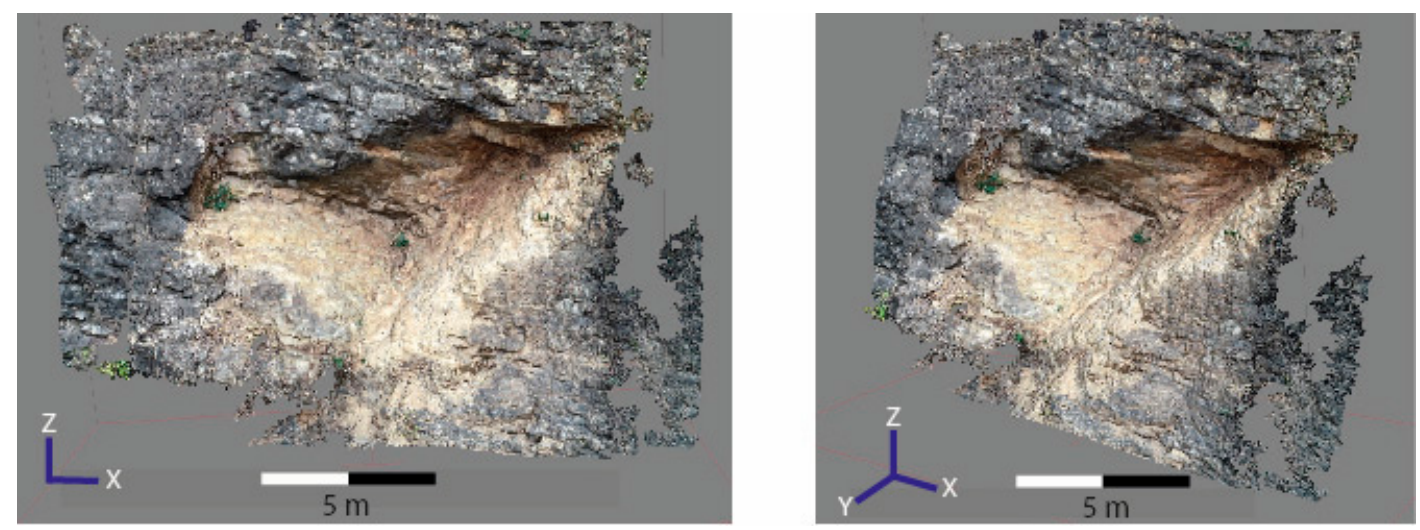

Figure 6. Front and right views of Sector 4 .

Based on the geomechanical classifications, we first evaluated the stability conditions in the studied sectors; then, we assessed the susceptibility to detachment; and finally, we determined the safety factor in the profiles that were considered the most critical of each sector. 


\section{Stability Conditions}

The SMR classifications by Romana [29] and the CSMR classification proposed by [30] were used for the analysis of stability conditions.

We decided to apply the SMR method because of its extensive use in stability assessment studies and also because it provides the basis for the CSMR method, which was deemed necessary due to the height of the scarp.

SMR

The SMR classification was originally published by [29], and it was improved in 1995 [31]. In 2001, correction factors were added to it (as detailed in [32]), and the Rock Mass Rating (RMR) classification, developed for tunnels [33], was adopted by [31] to be applied to slopes. The method is described in Table 2.

The SMR classifies the rocks by their stability, suggesting recommendations of support or corrections of problems (Table 3). To obtain the SMR, an "adjustment factor" (resulting from the multiplication of three subfactors $\left(\mathrm{F}_{1}, \mathrm{~F}_{2}\right.$, and $\left.\left.\mathrm{F}_{3}\right)\right)$ and an "excavation factor" $\left(\mathrm{F}_{4}\right)$ must be added to the RMR:

$$
\mathrm{SMR}=\mathrm{RMR}+\left(\mathrm{F}_{1} \times \mathrm{F}_{2} \times \mathrm{F}_{3}\right)+\mathrm{F}_{4}
$$

where $F_{1}$ is determined by the degree of parallelism between the strike of the discontinuities and the strike of the slope. It can be adjusted by the following expression:

$$
F_{1}=\left(1-\sin \left(\alpha_{j}-\alpha_{s}\right)\right)^{2}
$$

where $\alpha_{j}$ is the direction of dip of the joints, and $\alpha_{s}$ is the direction of the slope.

Table 2. Geomechanical classification: RMR and quality of the rock mass (modified from [5,33]).

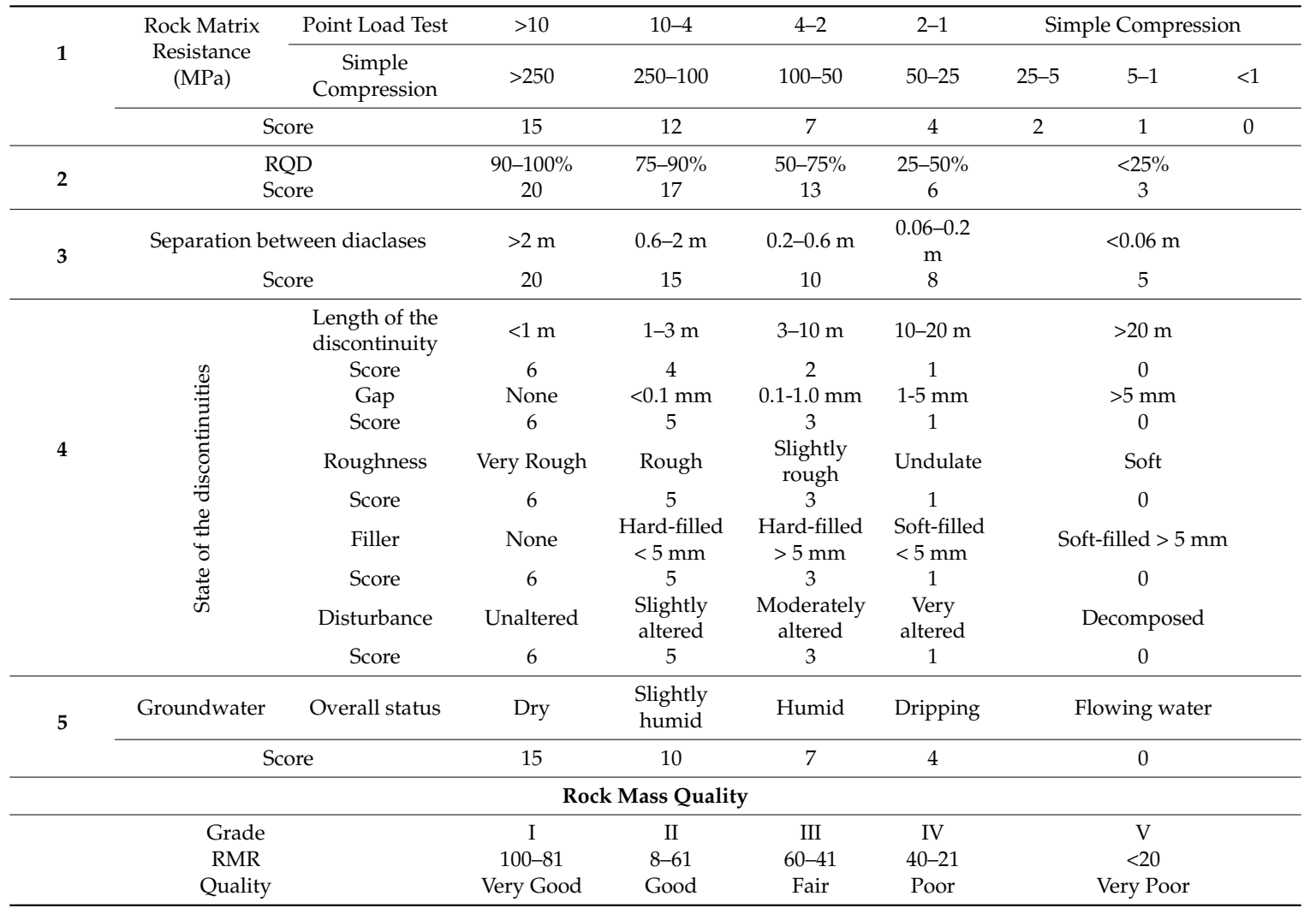


$\mathrm{F}_{2}$ : depends on the discontinuity dip $(\beta \mathrm{j})$ in the case of planar failure and the plunge (4):

$$
\mathrm{F}_{2}=\tan ^{2}\left(\beta_{\mathrm{j}}\right)
$$

where $\beta_{j}$ is the joint dip.

$\mathrm{F}_{3}$ is the relationship between the dip of the joint and the dip of the slope. With a higher inclination of the slope, the joints are more exposed and the conditions are less favorable.

$\mathrm{F}_{4}$ depends on the excavation methods of the slope, whether these are natural erosion processes or blasting techniques.

Table 3. Slope Mass Rating (SMR) classification of slopes. Source: [5].

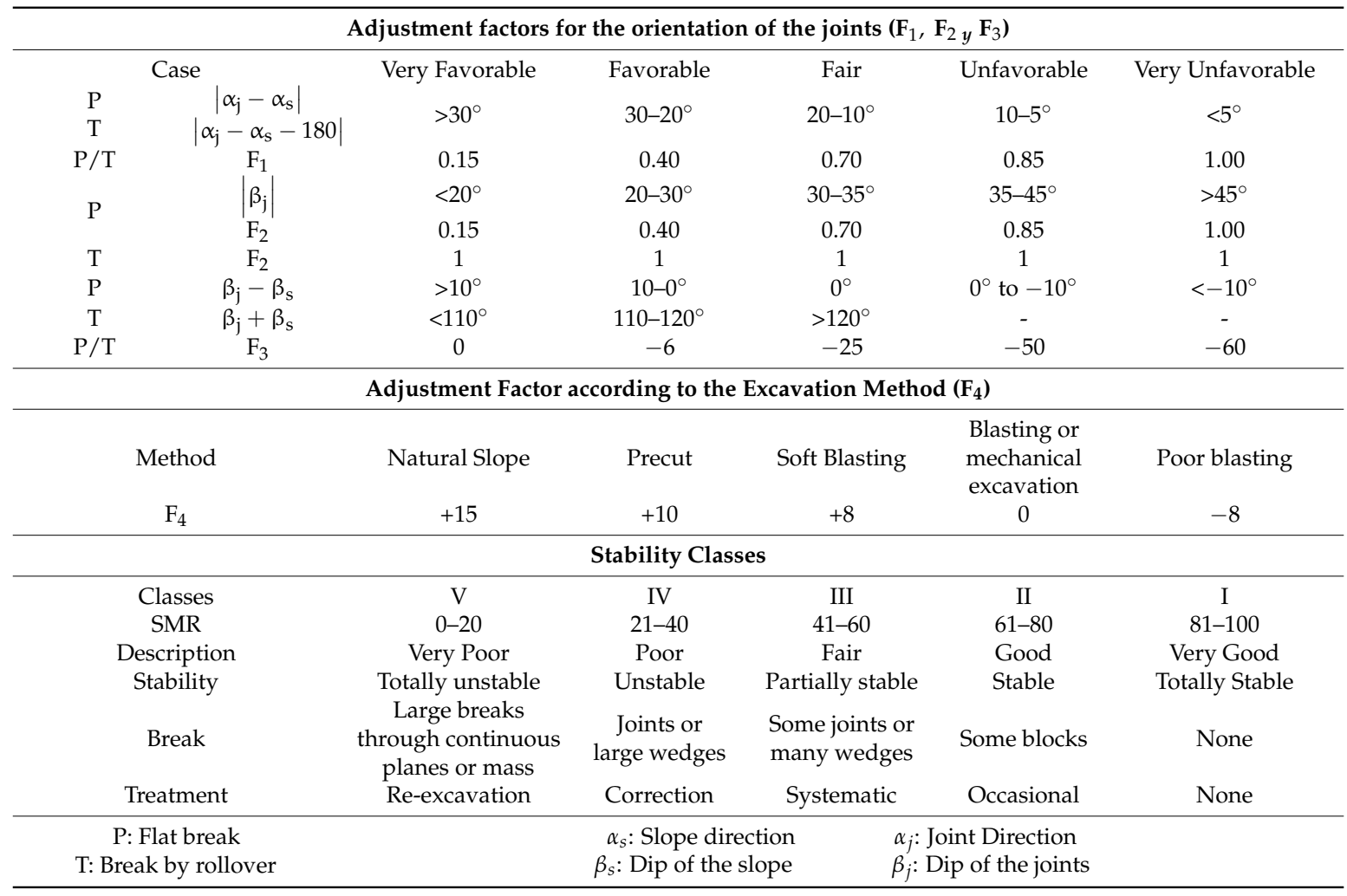

\section{CSMR}

The Chinese method [30] modifies the conventional SMR method by adding two coefficients, $\xi$ and $\lambda$, according to Equation (5):

$$
\operatorname{CSMR}=(\zeta \times \mathrm{RMR})-\left(\lambda \times \mathrm{F}_{1} \times \mathrm{F}_{2} \times \mathrm{F}_{3}\right)+\mathrm{F}_{4}
$$

where $\zeta$ is the slant height factor and, according to [34], is given by Formula (6):

$$
\mathrm{Z}=0.57+((0.43 \times 80) / \mathrm{H})
$$

where $\mathrm{H}$ is the slope height in meters, and $\lambda$ is the factor that describes the control conditions of the discontinuities (Table 4). 
Table 4. Discontinuity factor $\lambda$ (source: [30]).

\begin{tabular}{cc}
\hline$\lambda$ & Condition of Discontinuities \\
\hline 1.0 & Faults, long and weak joints filled with clays. \\
$0.9-0.8$ & Stratification plans, large-scale joints with the presence of water. \\
0.7 & Tightly linked joints and stratification planes \\
\hline
\end{tabular}

\section{Detachment Susceptibility}

To determine the detachment susceptibility of the studied slope, we applied a theoretical-practical approach based on the criteria of experts $[26,27,35,36]$ and the results obtained in its applications.

The considered parameters and the assigned scores are detailed in Table 5.

Table 5. Scores of the main parameters (source: $[26,27,35,36])$.

\begin{tabular}{cc}
\hline Main Parameters & Score Assigned in the Detachment Susceptibility Analysis (DS) \\
\hline Lithology & Up to 4.0 \\
Geological structure & Up to 4.0 \\
Morphometry and height & Up to 6.0 \\
Discontinuity and key blocks & Up to 6.0 \\
Water & Up to 6.0 \\
Vegetable cover & Up to 4.0 \\
Seismic & Up to 4.0 \\
Weathering Rank & Up to 4.0 \\
\hline
\end{tabular}

Following the method of [27] (modified by [37]), the values obtained for each parameter allowed for the classification of susceptibility into categories ranging from very low to very high (Table 6). This classification has been used by other authors [38-40].

Table 6. Classification of susceptibility.

\begin{tabular}{ccc}
\hline Susceptibility Category & $\begin{array}{c}\text { Detachment Susceptibility } \\
\text { Coefficient (DS) }\end{array}$ & Observations \\
\hline I & Very low susceptibility (DS < 8.0) & Stable conditions \\
\hline II & Low susceptibility & Stable conditions; \\
(DS between 8 and 15) & monitoring is required \\
\hline III & $\begin{array}{c}\text { Medium susceptibility } \\
\text { (DS between 15 and 21) }\end{array}$ & $\begin{array}{c}\text { Predominantly stable conditions; } \\
\text { systematic monitoring is required }\end{array}$ \\
\hline IV & $\begin{array}{c}\text { High susceptibility } \\
\text { (DS between 21 and 28) }\end{array}$ & Potentially unstable conditions \\
\hline V & Very high susceptibility (DS $>28)$ & Unstable conditions \\
\hline
\end{tabular}

\section{Calculation of the Safety Factor}

Eight profiles were developed in the slope (Figure 7), considering the different zones in which the slope was divided, its changes of direction, and extension. The safety factor was calculated for each profile using the Morgenstern-Price method [39], choosing for the analysis the lowest result of the safety factor. 


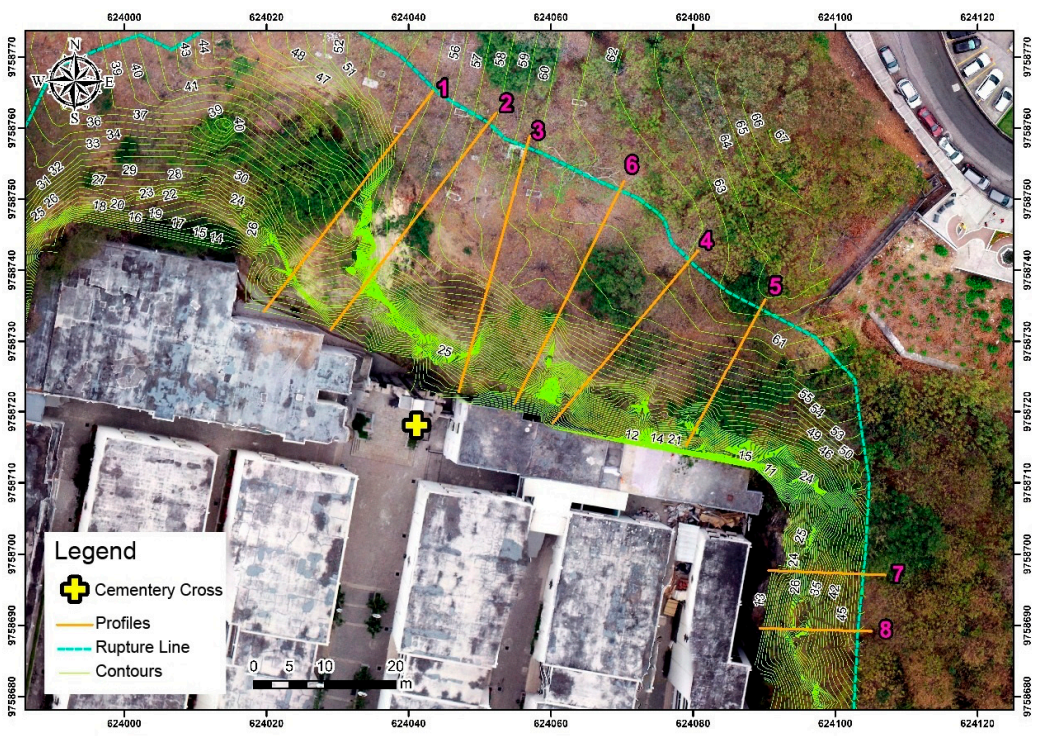

Figure 7. Location map of profiles for calculation of safety factor.

\section{Results}

\subsection{Geology}

\subsubsection{Stratigraphy}

The data collected in the field revealed a stratigraphy of silicified shales of shades of brown-to-gray color with the presence of calcareous material and calcareous sandstone intercalations of beige and dark gray color, with a granulometry that varies from fine to coarse throughout the outcrop and with

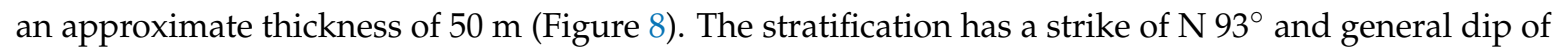
$19^{\circ} \mathrm{SW}$ approximately, with thicknesses of strata that vary from centimetric to decimetric.

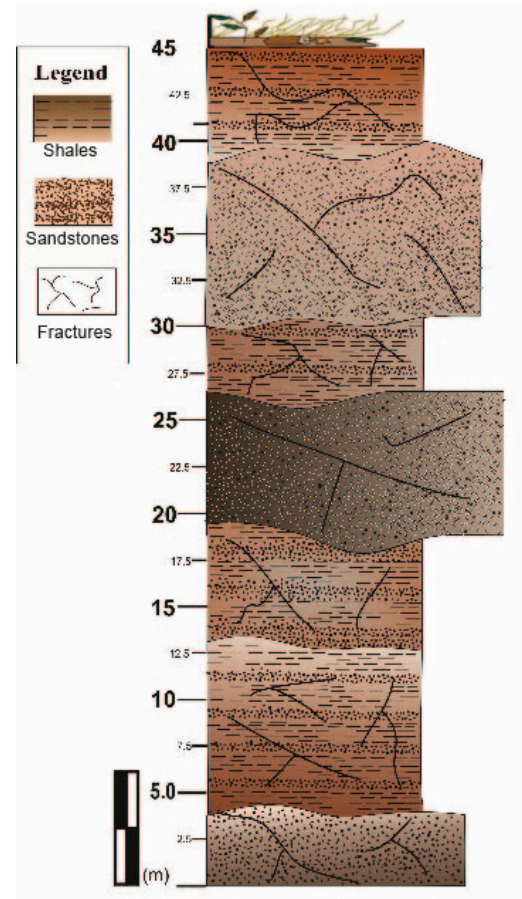

Intercalation of silicified decimetric shales and centimetric sandstones with structural measures of $\mathrm{N} 85^{\circ} / 20^{\circ} \mathrm{SE}$

Stratification of calcareous decimetric sandstones with structural measures of N85\% $/ 20^{\circ} \mathrm{SE}$

Intercalation of silicified decimetric shales and centimetric sandstones with structural measures of $\mathrm{N} 95^{\circ} / 19^{\circ} \mathrm{SW}$

Intercalation of silicified shales and calcareous decimetric sandstones at the base. In the upper part there are stratified calcareous sandstones with structural measures of N95\% $/ 19^{\circ} \mathrm{SE}$

Folded stratification of sandstones at the base with structural measures of $\mathrm{N} 92^{\circ} / 21^{\circ} \mathrm{SW}$. In the upper part there is an interlacement of decimetric shales with the presence of silica and sandstones with structural measures of N $59^{\circ} / 17^{\circ} \mathrm{SE}$

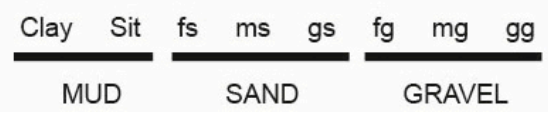

Figure 8. Slope stratigraphic column. 


\subsubsection{Geomechanical Characterization}

The results for each parameter are detailed in Table 7. They were used for the slope stability assessment (Tables 8-11).

Values of compression resistance (Table 7), RQD (Table 8), characteristics of discontinuities (Tables 9 and 10), and water presence (Table 11) intervened in the calculation of stability conditions (Table 12), while the results of density, cohesion, and internal friction angle (Table 7) were necessary to obtain the safety factor value (Table 13).

Physical-Mechanical Properties of Rocks

Table 7. Parameters obtained in laboratory.

\begin{tabular}{|c|c|c|c|c|c|c|}
\hline \multirow[b]{2}{*}{9} & \multirow{2}{*}{ Rock Type } & \multirow{2}{*}{ Description } & \multicolumn{2}{|c|}{ Physical-Mechanical Properties } & \multirow{2}{*}{$\begin{array}{l}\text { Cohesion } \\
\text { (MPa) }\end{array}$} & \multirow{2}{*}{$\begin{array}{r}\text { Internal } \\
\text { Friction } \\
\text { Angle ( }{ }^{\circ}\end{array}$} \\
\hline & & & $\begin{array}{l}\text { Density } \\
\left(\mathrm{g} / \mathrm{cm}^{3}\right)\end{array}$ & $\begin{array}{c}\text { Compression } \\
\text { Resistance (MPa) }\end{array}$ & & \\
\hline 1 & $\begin{array}{l}\text { Calcareous } \\
\text { sandstone }\end{array}$ & $\begin{array}{l}\text { Dark gray and } \\
\text { medium grained }\end{array}$ & 2.30 & 117.60 & 18.00 & $38-40$ \\
\hline 2 & Silicified shale & $\begin{array}{l}\text { Brown and fine } \\
\text { grained }\end{array}$ & 2.29 & 107.50 & 16.60 & $42-46$ \\
\hline 3 & Silicified shale & $\begin{array}{l}\text { Brown and fine } \\
\text { grained }\end{array}$ & 2.59 & 118.50 & 18.00 & $40-46$ \\
\hline 4 & Sandstone & $\begin{array}{l}\text { Light gray and } \\
\text { fine-to-medium } \\
\text { grained }\end{array}$ & 2.16 & 112.20 & 17.40 & $36-38$ \\
\hline 5 & $\begin{array}{l}\text { Calcareous } \\
\text { sandstone }\end{array}$ & $\begin{array}{l}\text { Light gray and } \\
\text { fine-to-medium } \\
\text { grained }\end{array}$ & 2.38 & 116.00 & 14.90 & $40-42$ \\
\hline 6 & Sandstone & $\begin{array}{l}\text { Gray and } \\
\text { medium grained }\end{array}$ & 2.32 & 111.20 & 15.50 & $38-40$ \\
\hline
\end{tabular}

RQD

Table 8. RQD percentage and classification of rocks for all sectors of the slope.

\begin{tabular}{cccc}
\hline Zone & Sector & RQD (\%) & Classification \\
\hline \multirow{2}{*}{1} & 1 & 45.27 & Poor \\
& 2 & 51.05 & Fair \\
\hline & 3 & 55.51 & Fair \\
& 4 & 67.16 & Fair \\
& 5 & 60.50 & Fair \\
& 6 & 71.14 & Fair \\
& 7 & 73.58 & Fair \\
& 8 & 74.80 & Fair \\
& 9 & 65.12 & Fair \\
\hline \multirow{2}{*}{3} & 10 & 66.79 & Fair \\
& 11 & 63.19 & Fair \\
\hline
\end{tabular}

Characteristics of Discontinuities

Table 9. Separation between diaclases for all sectors of the slope.

\begin{tabular}{cccc}
\hline Zone & Sector & Average Separation $(\mathbf{m})$ & Score \\
\hline \multirow{2}{*}{1} & 1 & 0.17 & 8 \\
& 2 & 0.17 & 8 \\
\hline
\end{tabular}


Table 9. Cont.

\begin{tabular}{cccc}
\hline Zone & Sector & Average Separation $(\mathbf{m})$ & Score \\
\hline & 3 & 0.32 & 10 \\
& 4 & 0.32 & 10 \\
2 & 5 & 0.26 & 10 \\
& 6 & 0.34 & 10 \\
& 7 & 0.24 & 10 \\
& 8 & 0.31 & 10 \\
& 9 & 0.29 & 10 \\
\hline \multirow{3}{*}{3} & 10 & 0.26 & 10 \\
& 11 & 0.38 & 10 \\
\hline
\end{tabular}

Table 10. Joint conditions for all sectors of the slope.

\begin{tabular}{|c|c|c|c|c|c|c|}
\hline Zone & Sector & Discontinuity Length (m) & Gap (mm) & Roughness & Filler & Disturbance \\
\hline \multirow[t]{2}{*}{1} & 1 & \multirow{11}{*}{$\begin{array}{c}3-10 \\
\text { Score }=10\end{array}$} & \multirow{11}{*}{$\begin{array}{c}0.1-1 \\
\text { Score = } 3\end{array}$} & \multirow{11}{*}{$\begin{array}{l}\text { Undulated } \\
\text { Score = } 1\end{array}$} & \multirow{9}{*}{$\begin{array}{c}\text { Soft }<5 \mathrm{~mm} \\
\text { Score }=2\end{array}$} & $\begin{array}{l}\text { Moderate } \\
\text { Score }=3\end{array}$ \\
\hline & 2 & & & & & \multirow{4}{*}{$\begin{array}{c}\text { Very altered } \\
\text { Score }=1\end{array}$} \\
\hline \multirow{7}{*}{2} & 3 & & & & & \\
\hline & 4 & & & & & \\
\hline & 5 & & & & & \\
\hline & 6 & & & & & $\begin{array}{c}\text { Very altered } \\
\text { Score }=3\end{array}$ \\
\hline & 7 & & & & & $\begin{array}{c}\text { Very altered } \\
\text { Score }=1\end{array}$ \\
\hline & 8 & & & & & $\begin{array}{l}\text { Moderate } \\
\text { Score }=3\end{array}$ \\
\hline & 9 & & & & & Very altered \\
\hline \multirow{2}{*}{3} & 10 & & & & \multirow{2}{*}{$\begin{array}{c}\text { None } \\
\text { Score }=6\end{array}$} & Score $=3$ \\
\hline & 11 & & & & & \\
\hline
\end{tabular}

Water Presence

Table 11. Water presence for all sectors of the slope.

\begin{tabular}{|c|c|c|c|}
\hline Area & Sectors & Water Flow in the Joints & Score \\
\hline \multirow{2}{*}{1} & 1 & Dry & 15 \\
\hline & 2 & Slightly humid & 10 \\
\hline \multirow{7}{*}{2} & 3 & Flowing water & 0 \\
\hline & 4 & Humid & 7 \\
\hline & 5 & Dripping & 4 \\
\hline & 6 & \multirow{2}{*}{ Slightly humid } & 10 \\
\hline & 7 & & 10 \\
\hline & 8 & \multirow{4}{*}{ Dry } & 15 \\
\hline & 9 & & 15 \\
\hline \multirow{2}{*}{3} & 10 & & 15 \\
\hline & 11 & & 15 \\
\hline
\end{tabular}




\subsection{Evaluation of Stability}

\subsubsection{Stability Conditions}

Table 12. Results of the analysis of stability conditions.

\begin{tabular}{ccccccc}
\hline \multirow{2}{*}{ Zone } & \multirow{2}{*}{ Sector } & \multirow{2}{*}{ RMR (\%) } & \multirow{2}{*}{ SMR (\%) } & \multirow{2}{*}{ CSMR (\%) } & \multicolumn{2}{c}{ Classification } \\
\cline { 6 - 7 } & & & & & SMR & CSMR \\
\hline \multirow{2}{*}{1} & 1 & 54 & 44.71 & 45.45 & Fair & Fair \\
& 2 & 52 & 41.21 & 43.45 & Fair & Fair \\
\hline & 3 & 44 & 32.93 & 33.85 & Poor & Poor \\
& 4 & 51 & 39.93 & 40.85 & Poor & Poor \\
& 5 & 48 & 36.93 & 37.85 & Poor & Poor \\
& 6 & 56 & 44.93 & 45.85 & Fair & Fair \\
& 7 & 54 & 42.93 & 43.85 & Fair & Fair \\
& 8 & 61 & 49.93 & 50.85 & Fair & Fair \\
& 9 & 59 & 47.93 & 48.85 & Fair & Fair \\
\hline \multirow{2}{*}{3} & 10 & 65 & 52.84 & 54.09 & Fair & Fair \\
& 11 & 65 & 52.84 & 54.09 & Fair & Fair \\
\hline
\end{tabular}

\subsubsection{Detachment Susceptibility and Safety Factor}

Table 13 shows the results of detachment susceptibility obtained for each studied sector together with their qualification according to the reference table (Table 12). The zoning map for the sector and the values obtained from the SF for the different profiles (Figures 9-11) are also displayed.
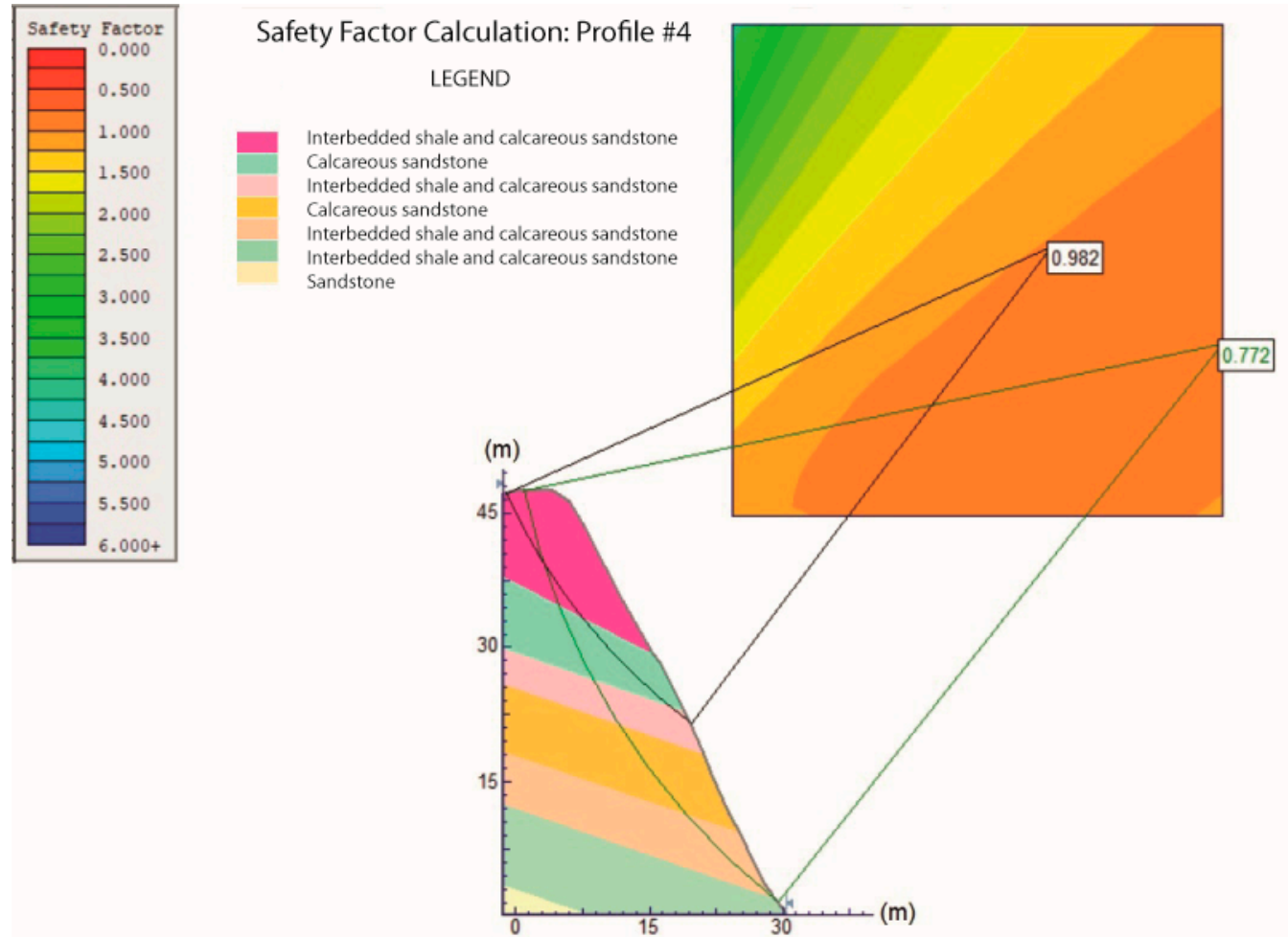

Figure 9. Safety factor calculation for the topographic profile no. 4. 


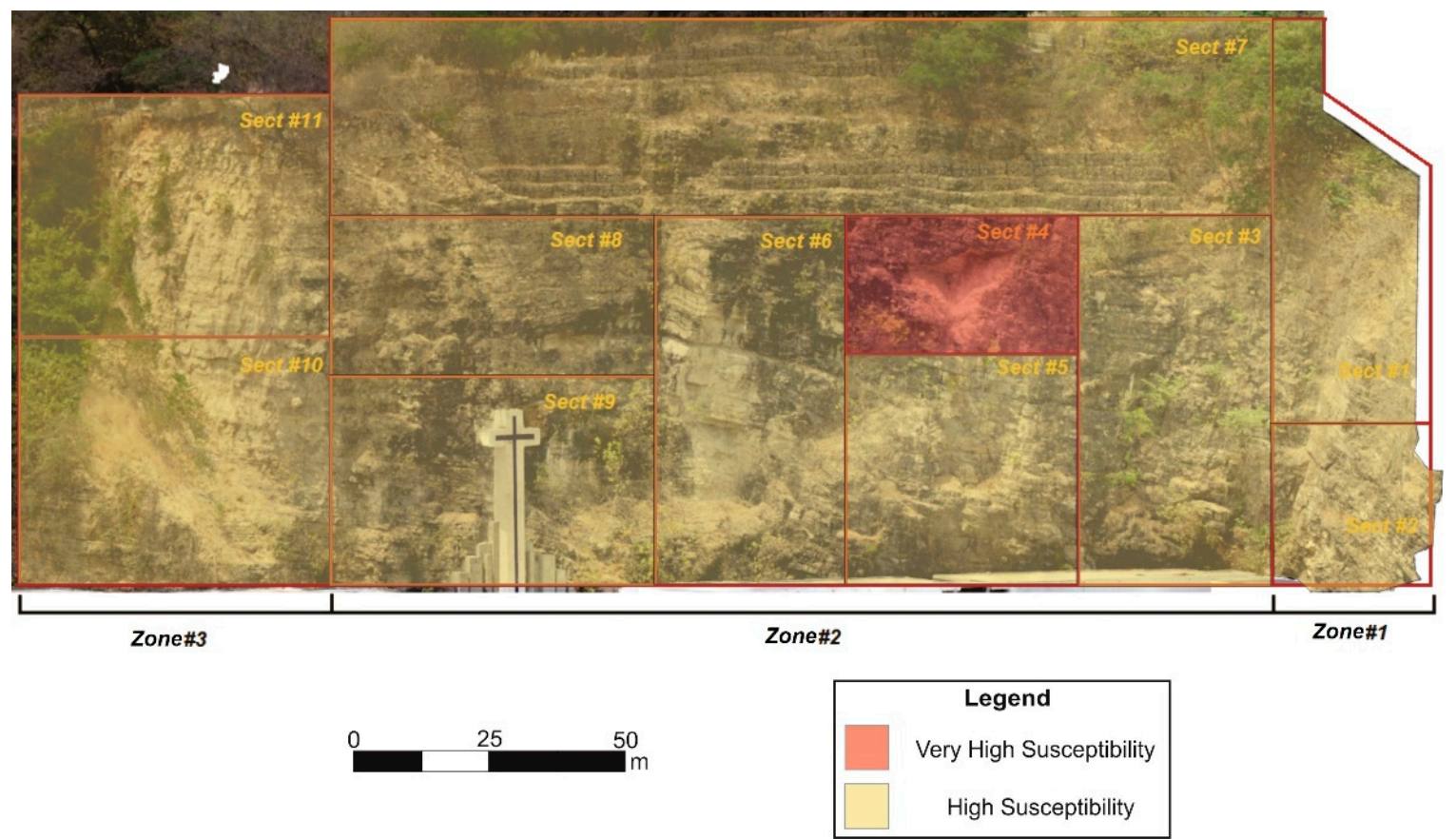

Figure 10. Susceptibility to normal conditions.

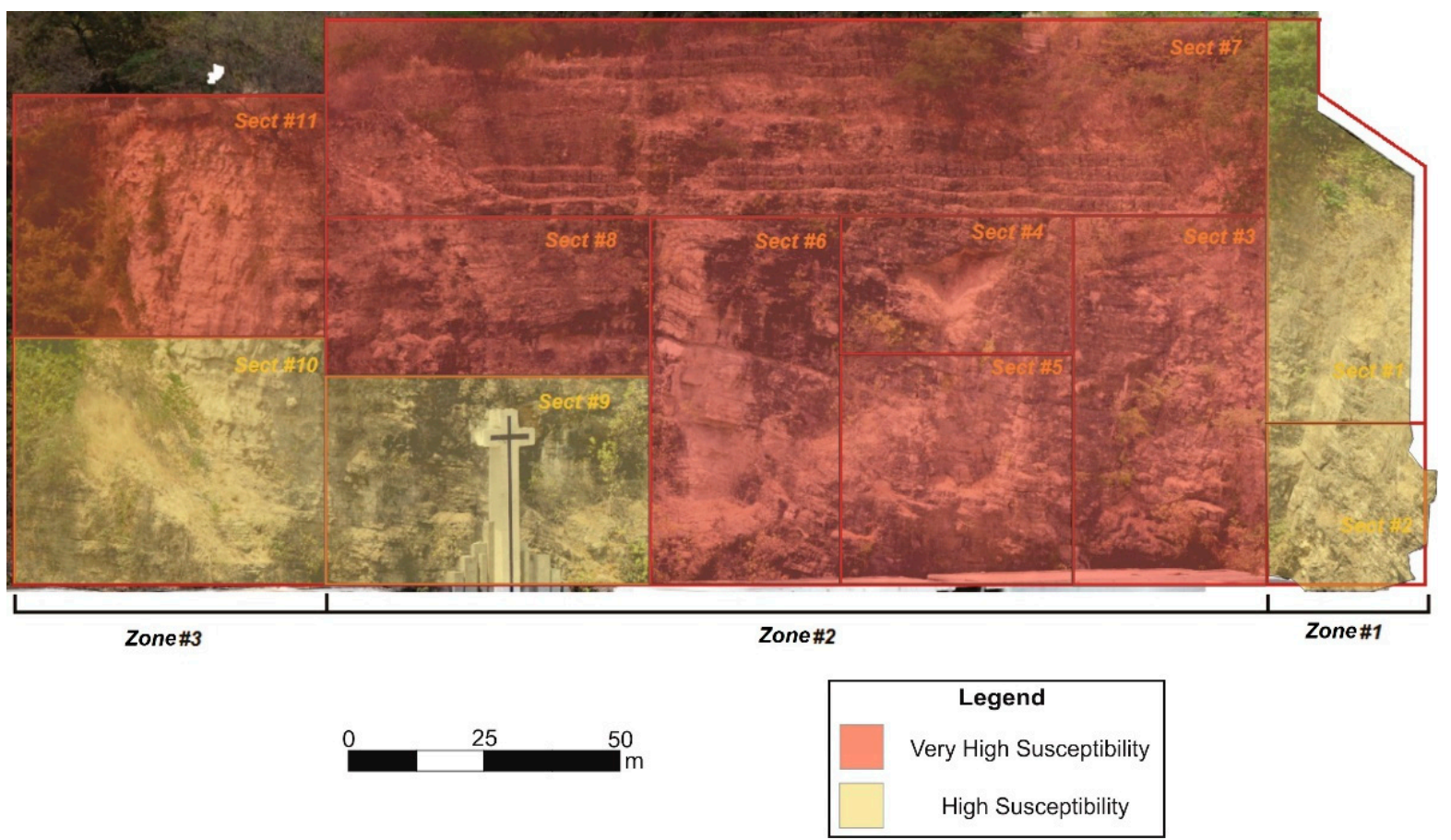

Figure 11. Susceptibility to extreme conditions. 
Table 13. Results of detachment susceptibility.

\begin{tabular}{|c|c|c|c|c|c|c|}
\hline Zone & Sector & $\begin{array}{c}\text { Susceptibility: } \\
\text { Current Conditions }\end{array}$ & $\begin{array}{c}\text { Susceptibility: } \\
\text { Extreme Conditions }\end{array}$ & Profile & $\begin{array}{c}\text { Hypothetical } \\
\text { Safety Factor (SF) }\end{array}$ & Real SF \\
\hline \multirow[b]{2}{*}{1} & 1 & High & High & 7 & 0.606 & 0.996 \\
\hline & 2 & High & High & 8 & 0.681 & 0.995 \\
\hline \multirow{7}{*}{2} & 3 & High & Very High & & & \\
\hline & 4 & Very High & Very High & & & \\
\hline & 5 & High & Very High & 3 & 0.677 & 0.997 \\
\hline & 6 & High & Very High & 4 & 0.759 & 0.982 \\
\hline & 7 & High & Very High & 5 & 0.690 & 0.989 \\
\hline & 8 & High & Very High & & 0.725 & 0.996 \\
\hline & 9 & High & High & & & \\
\hline \multirow[b]{2}{*}{3} & 10 & High & High & 1 & 0.831 & 0.996 \\
\hline & 11 & High & Very High & 2 & 0.892 & 0.999 \\
\hline
\end{tabular}

\section{Interpretation of Results and Discussion}

The lithology of the study area corresponds to the Upper Member of Guayaquil Formation formed by calcareous sandstones and silicified shales in accordance with the information published in [17]. The direction of dip of the strata favors wedge failure.

The similarity of the results obtained with the SMR and CSMR methods allowed us to corroborate the obtained rank of scarp stability. The values are within classes III and IV; that is, a fair-to-poor stability range according to the SMR geomechanical classification table [5]. Sectors 3-5 of the massif have the lowest stability values due to the presence of water, which makes them the most susceptible.

The determined susceptibility was based on a combination of methods that consider various geomechanical parameters described in the literature $[26,27,35,36]$. This allowed us to establish different zones in the study area according to the conditions of detachment.

A safety factor with a value lower than 1 indicates that the slope is unstable [40]. Two safety factors were calculated for each topographic profile. The first one was a hypothetical SF, which was obtained considering a detachment plane that corresponded to the entire height of the slope. This situation was clearly unrealistic as the slope would fail way before. The second, "real" SF identified the critical point where the instability of the slope might start.

Figure 9 illustrates the above methods. It shows a topographic profile of the slope together with the two detachment surfaces and the corresponding SF values. The hypothetical SF was 0.772, which was only relevant for comparative analysis. The real SF was 0.982 , and it represents the current situation of the slope and the surface below which the slope becomes unstable.

The safety factor illustration (Figure 9) corresponded to the topographic profile no. 4 (Figure 7), the average dip of the strata was $19^{\circ}$, and the lithology is shown in Figure 8. The possible detachment surfaces follow lithostratigraphic changes, such as the one around $23 \mathrm{~m}$ in the stratigraphic column. This fits the value of the real SF of Figure 9, a fact that offers a relationship between the safety factor values and physical-mechanical properties of the rock.

The applied procedure has been used in similar studies [27] combining traditional techniques of geomechanical characterization $[19-24,29,30]$ with novel techniques, such as the use of drones. The described systematic application of qualitative and quantitative methods for slope stability estimation could be used in other zones with similar problems.

\section{Conclusions}

The state of the slope was determined by a geomechanical study that included the assessment of stability and detachment susceptibility and the calculation of the safety factor. The obtained results revealed a slope with high failure susceptibility and low stability that requires urgent remediation measures to ensure the integrity of the cemetery, the heritage enclosed therein, and the people who attend the place. 
The obtained SMR values were between 32.93 and 52.84, while the CSMR values were found to be between 33.85 and 54.09 . The results yielded by the two methods were practically identical and represent a classification of the stability conditions from fair to poor. In Sectors 3-5 of the escarpment, particularly unfavorable stability conditions are present.

The results obtained, considering no precipitation and without seismic influence, yielded very high susceptibility in Sector 4, while the other sectors have a high susceptibility to detachment. When high precipitations were considered together with the possible effect of seismic activity (taking into account that Guayaquil is located in a seismically active area), the detachment susceptibility was found to be very high for Sectors $3-8$ and 11 and high for the others.

The safety factor was calculated for eight escarpment profiles, and the value of 0.982 was taken as the most critical one.

The obtained safety factors are in good agreement with the values of detachment susceptibility, which demonstrates the reliability of the obtained results.

\section{Recommendations}

For a more reliable analysis of stability conditions for high slopes, the CSMR method is recommended because it takes into account the height of the slope and the state of the discontinuities.

The slope should be stabilized using a bolting technique with uniform distribution over the entire surface of the slope (Figure 12), applying gunite (shotcrete) placed in two layers. Due to the conditions of certain parts of the cemetery, the use of metallic meshes is also recommended in order to avoid the detachment of rock fragments.

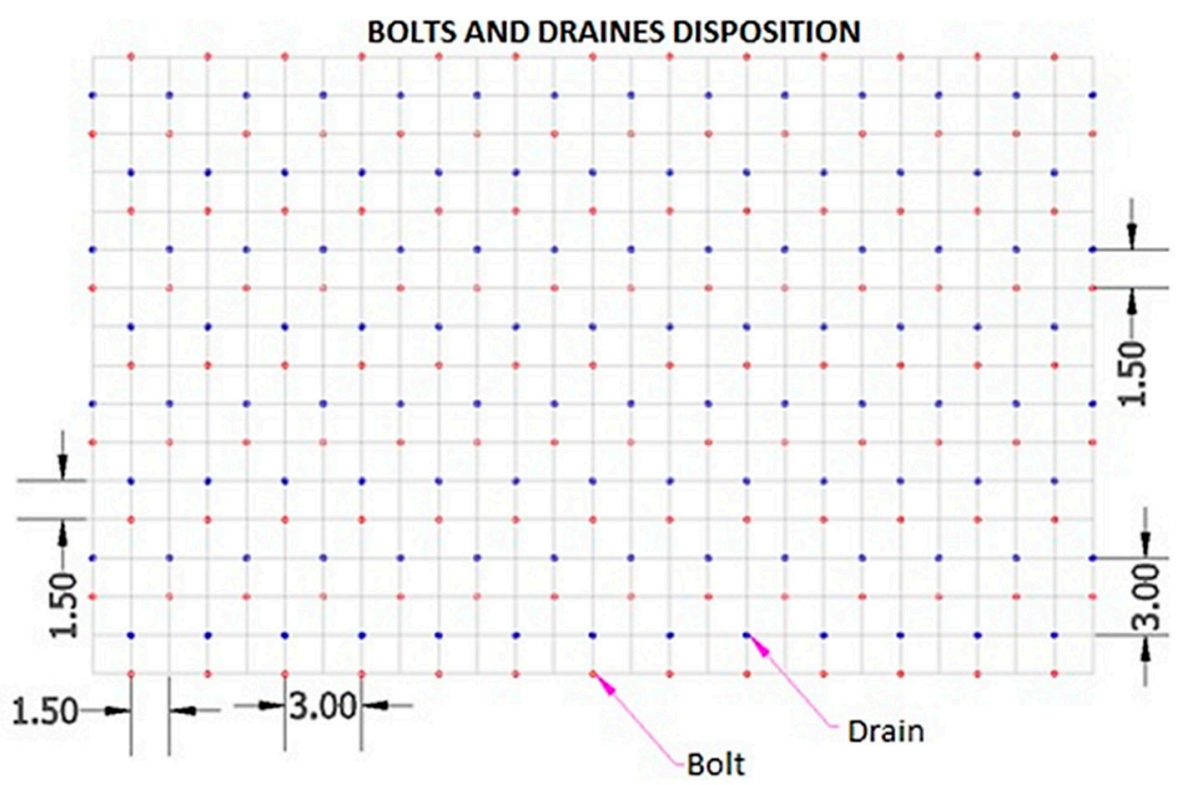

Figure 12. Distribution system of bolts and drains. Red dots represent bolts while the drains are shown in blue. Measures are given in meters.

Author Contributions: Investigation, M.A., G.R., J.B., and E.B.; Supervision, F.M., R.B., and P.C.; Validation, R.B.; Writing-review \& editing, J.B., and E.B.

Funding: This research received no external funding.

Acknowledgments: The authors are grateful to ESPOL (Polytechnic University, Ecuador) and IGME (Geological Survey of Spain) for their supporting in this research. Thanks are due to Timea Kovacs for her suggestions. We also would like to thank two anonymous reviewers for their constructive comments and the editorial office for the editorial handling.

Conflicts of Interest: The authors declare no conflict of interest. 


\section{Abbreviations}

$\begin{array}{ll}\text { SMR } & \text { Slope Mass Rating } \\ \text { CSMR } & \text { Chinese Slope Mass Rating } \\ \text { SF } & \text { Safety Factor } \\ \text { RQD } & \text { Rock Quality Designation } \\ \text { RMR } & \text { Rock Mass Rating } \\ F & \text { Factors } \\ \lambda & \text { Condition of Discontinuities } \\ \text { DS } & \text { Detachment Susceptibility Coefficient }\end{array}$

\section{References}

1. De Matteis, Á.; Estabilidad de Taludes. Rosario: Facultad de C.S. Exactas, Ingeniería y Agrimensura, Universidad Nacional de Rosario. 2003. Available online: https://www.fceia.unr.edu.ar/ geologiaygeotecnia/Estabilidad\%20de\%20Taludes.pdf (accessed on 25 February 2019).

2. Varnes, D.J.; Cruden, D.M. Landslide Types and Processes. Available online: http://onlinepubs.trb.org/ Onlinepubs/sr/sr29/29-003.pdf (accessed on 29 December 2018).

3. Penning-Rowsell, E.C.; Smith, K. Environmental Hazards: Assessing Risk and Reducing Disaster. Geogr. J. 1993, 159, 349. [CrossRef]

4. Kresna, B.N.; Bahagiarti, S.; Purwanto, P. Geology and Slope Stability Analysis using Markland Method on Road Segment of Piyungan-Patuk, Sleman and Gunungkidul Regencies, Yogykarta Special Region, Indonesia. Inter. J. Econ. Environ. Geol. 2016, 7, 42-52.

5. González de Vallejo, L.I.; Ferrer, M.; Ortuño, L.; Oteo, C. Ingeniería Geológica; Prentice Hall-Pearson Educación: Madrid, Spain, 2002; p. 750.

6. Pérez, E. Estabilidad de Taludes; Canals i Ports Universitat Politècnica de Catalunya: Catalunya, Spain, 2005 ; p. 61.

7. Alpízar, A. Metodología de Análisis de Estabilidad de Taludes Para Proyectos Vials; XI Congreso Nacional de Geotecnia: Congeo, Costa Rica, 2012.

8. Salazar, D.G. Diseño de un Plan Piloto Turístico Educativo Sobre el Cementerio Patrimonial de Guayaquil, Dirigido a los Estudiantes de la Escuela Dr. Avellán Vite de 4to a 7 mo año de Educación Básica. Licenciado; Turismo y Hotelería-Universidad de Guayaquil: Guayaquil, Ecuador, 2017.

9. Guayaquil es mi Destino. Available online: http://www.guayaquilesmidestino.com/ (accessed on 23 December 2018).

10. Morante, F.E. Las Zeolitas de la Costa de Ecuador (Guayaquil): Geología, Caracterización y Aplicaciones. Ph.D. Thesis, Ciencias-Universidad Politécnica de Madrid, Madrid, Spain, 2004.

11. Alemán, A. Informe Geológico de la Cuenca Progreso; Informe no publicado para la Compañía Duke Energy: Guayaquil, Ecuador, 1999.

12. Núñez del Arco, E. Geología del Ecuador; Escuela Superior Politécnica del Litoral: Guayaquil, Ecuador, 2003; p. 275.

13. Olsson, A. Tertiary deposits of NO south America and Panamá. 8th Am. Sci. Congr. Washington. Geol. Sci. 1942, 4, 231-287.

14. Benítez, S.B. Estratigrafía de las formaciones Cayo y Guayaquil en la cordillera Chongón Colonche: Hacia una redefínición. Geocienc. Rev. del CIGMP Guayaquil 1990, 3, 7-11.

15. Lopez Coronel, M.C. Análisis Estructural de la Cuenca Progreso- Secuencias Paleógenas. Ph.D. Thesis, Ingeniería en Geología-Escuela Superior Politécnica del Litoral, Guayaquil, Ecuador, 2016.

16. Thalmann, H. Micropaleontology of Upper Cretaceous and Paleoceno in Western Ecuador. Am. Assoc. Pet. Geol. Bull. 1946, 30, 337-347.

17. Benitez, S. Évolution géodynamique de la province côtière sud-équatorienne au Crétacé supérieur- Tertiaire. Available online: http:/ /geologie-alpine.ujf-grenoble.fr/articles/GA_1995_71_3_0.pdf (accessed on 29 December 2018).

18. Centro de Investigaciones y Proyectos Aplicados a la Tierra "CIPAT". Estudios y Propuestas de Estabilización del Talud en el Cerro del Carmen del Cementerio General; Informe no publicado para la Junta de Beneficencia de Guayaquil realizado por ESPOLTECH E.P.; Guayaquil Charity Board (Junta de Beneficencia de Guayaquil): Guayaquil, Ecuador, 2018. 
19. Li, D.; Wong, L.N.Y. The Brazilian Disc Test for Rock Mechanics Applications: Review and New Insights. Rock Mech. Rock Eng. 2012, 46, 269-287. [CrossRef]

20. Ma, T.; Peng, N.; Zhu, Z.; Zhang, Q.; Yang, C.; Zhao, J. Brazilian Tensile Strength of Anisotropic Rocks: Review and New Insights. Energies 2018, 11, 304. [CrossRef]

21. Akazawa, T. New test method for evaluating internal stress due to compression of concrete: The splitting tension test. J. Jpn. Soc. Civ. Eng 1943, 29, 777-787.

22. Carneiro, F.L.L.B. A new method to determine the tensile strength of concrete. In Proceedings of the 5th Meeting of the Brazilian Association for Technical Rules, Lisbon, Portugal, 16 September 1943; pp. 126-129.

23. Stagg, K.G.; Zienkiewicz, O.C. Rock Mechanics in Engineering Practice; Wiley: New York, NY, USA, 1968; p. 442.

24. Deere, D.U.; Deere, D.W. Rock Quality Designation (RQD) after twenty years; U.S. Army Engineer Waterways Experiment Station: Vicksburg, MS, USA, 1988; p. 101.

25. Priest, S.D.; Hudson, S.D. Discontinuity spacings in rock. Inter. J. Rock Mech. Min. Sci. Geomech. Abstr. 1976, 13, 135-148. [CrossRef]

26. Suarez, J. Deslizamientos y Estabilidad de Taludes en Zonas Tropicales; Instituto de Investigaciones sobre Erosión y Deslizamientos: Bucaramanga, Colombia, 1998; p. 550.

27. Blanco, R. Estudios y Propuestas de Estabilización del Cerro Las Cabras; Informe no publicado para la Municipalidad de Durán realizado por CIPAT-ESPOL; Duran Municipality: Duran, Ecuador, 2015.

28. Anbalagan, R.; Chakraborty, D.; Kohli, A. Landslide hazard zonation (LHZ) mapping on meso-scale for systematic town planning in mountainous terrain. J. Sci. Ind. Res. 2008, 67, 486-497.

29. Romana, M. A geomechanical classification for slopes: Slope Mass Rating: Principles, Practice and Projects. In Rock Testing and Site Characterization; Elsevier: Amsterdam, The Netherlands, 1993.

30. Chen, Z. Recent Developments in Slope Stability Analysis. Inter. Soc. Rock Mech. Rock Eng. 1995, 8, 1041-1048.

31. Romana, M. The Geomechanical Classification SMR for Slope Correction. Inter. Soc. Rock Mech. Rock Eng. 1995, 8, 1085-1092.

32. Romana Ruiz, M.; Serón Gáñez, J.B.; Montalar Yago, E. La clasificación geomecánica SMR: Aplicación, Experiencias y Validación; V Simposio Nacional sobre Taludes y Laderas Inestables: Madrid, Spain, 2001.

33. Bieniawski, Z.T. Engineering Rock Mass Classifications: A Complete Manual for Engineers and Geologists in Mining, Civil, and Petroleum Engineering; John Wiley and Sons: New York, NY, USA, 1989.

34. Anbalagan, R. Landslide hazard evaluation and zonation mapping in mountainous terrain. Eng. Geol. 1992, 32, 269-277. [CrossRef]

35. Nicholson, D.; Hencher, S. Assessing the Potential for Deterioration of Engineered Rockslopes. Available online: https:/ / www.researchgate.net/publication/209804864_Assessing_the_potential_for_deterioration_ of_engineered_rockslopes (accessed on 29 December 2018).

36. Román, A.Q.; Feoli-Boraschi, S. Comparación de la Metodología Mora-Vahrson y el Método Morfométrico para Determinar Áreas Susceptibles a Deslizamientos en la Microcuenca del Río Macho, Costa Rica. REVGEO 2018, 1, 17-45.

37. Barrantes, G.; Barrantes, O.; Núñez, O. Efectividad de la metodología Mora-Vahrson modificada en el caso de los deslizamientos provocados por el terremoto de Cinchona, Costa Rica. Revista Geográfica de América Central 2011, 2, 141-162.

38. Sánchez, C.; Sánchez, A. Evaluación de Amenazas Geodinámicas en el Entorno de la Actividad Minera en la Concesión Minera Palacios. Ph.D. Thesis, Escuela Superior Politécnica del Litoral, Guayaquil, Ecuador, 2018.

39. Morgenstern, N.R.; Price, V.E. The Analysis of the Stability of General Slip Surfaces. Géotechnique 1965, 15, 79-93. [CrossRef]

40. Melentijevic, S. Estabilidad de Taludes en Macizos Rocosos con Criterios de Rotura no Lineales y Leyes de Fluencia no Asociada. Ph.D. Thesis, Universidad Politécnica de Madrid, Madrid, Spain, 2005.

(C) 2019 by the authors. Licensee MDPI, Basel, Switzerland. This article is an open access article distributed under the terms and conditions of the Creative Commons Attribution (CC BY) license (http://creativecommons.org/licenses/by/4.0/). 